\title{
KERAGAMAN GENETIK IKAN TIGER FISH (Datnioides sp.) ASAL KALIMANTAN DAN SUMATERA
}

\author{
Melta Rini Fahmi”, Erma Primanita Hayuningtyas, Mochammad Zamroni, Bastiar Nur, dan \\ Shofihar Sinansari
}

Balai Riset Budidaya Ikan Hias

Jl. Perikanan No. 13, Pancoran Mas, Depok 16436

(Naskah diterima: 19 Maret 2018; Revisi final: 10 Juli 2018; Disetujui publikasi: 10 Juli 2018)

\begin{abstract}
ABSTRAK
Ikan tiger fish (Datnioides sp.) merupakan ikan hias air tawar yang memiliki nilai ekonomis penting. Distribusi populasi ikan ini meliputi Papua, Kalimantan, dan Sumatera, dengan tingkat eksploitasi yang cukup tinggi di dua lokasi terakhir. Penelitian ini dilakukan untuk mendapatkan informasi keragaman genetik ikan tiger fish yang mendiami perairan Kalimantan dan Sumatera. Sebanyak 24 sampel ikan uji dikoleksi dari Sungai Kapuas, Kalimantan Barat dan Sungai Musi, Sumatera Selatan. Penelitian dilakukan dalam dua tahap, tahap pertama yaitu identifikasi molekuler dengan menggunakan DNA barcoding gen cytochrome oxidase 1 (COI), tahap kedua adal ah analisis keragaman genetik dengan menggunakan marka DNA mitokondria gen cytochrome $b$ (Cyt b), dan DNA inti gen recombination activating gene(RAG2). Hasil identifikasi secara molekuler menunjukkan bahwa ikan hasil koleksi memiliki kesamaan genetik sebesar $100 \%$ dengan spesies D. undecimradiatus. Keragaman genetik ikan tiger fish antar populasi berkisar pada nilai 0,023 (standar deviasi 0,001) sedangkan keragaman intra populasi adalah sebesar 0,002 dan 0,003 masing-masing untuk populasi Kalimantan dan Sumatera. Jarak genetik sampel baik yang berasal dari Sumatera maupun Kalimantan dengan spesies D. undeciumradiatus masing-masing 0,003 dan 0,006; sedangkan dengan spesies D. microlepis yaitu 0,142. Analisis menggunakan gen RAG2 menunjukkan sampel yang diuji memiliki struktur populasi yang terpisah ditandai dengan terjadinya mutasi pada enam nukleotida dan tiga asam amino.
\end{abstract}

\section{KATA KUNCl: Datnioides sp.; tiger fish; keragaman genetik; DNA barcoding}

ABSTRACT: Genetic diversity of indonesian tiger fish (Datnioides sp.) from Kalimantan and Sumatera. By: Melta Rini Fahmi, Erma Primanita Hayuningtyas, Mochammad Zamroni, Bastiar Nur, and Shofihar Sinansari

The Tiger fish (Datnioides sp.) is a freshwater ornamental fish that hasimportant economic value. The distribution of this fish included Papua, Kalimantan, and Sumatra, but intensive exploitation occurs in the last two population. This research was conducted to obtain the genetic diversity of tiger fish that inhabited in Kalimantan and Sumatra. A total of 24 fish were collected from Kapuas River, West Kalimantan and M usi River, at Sumatra. The study was conducted in two stages, the first stage is molecular identification of sample by using DNA barcoding cytochrome oxidase 1 (COI) gene, the second stage is analyses of genetic diversity of tiger fish within and between population by using the mitochondrial DNA cytochromeb (Cyt b) gene, and nucleus DNA recombination (RAG2) gene. The molecular identification has shown that the collected fish has a genetic similarity of $100 \%$ with $\mathbf{D}$. undecimradiatus. The genetic diversity of tiger fish between populations is 0.023 (standard deviation of 0.001 ) whereas intra-population is 0.002 and 0.003 for Kalimantan and Sumatra, respectively. The genetic distance of samples with species $\mathbf{D}$. undeciumradiatus were 0.003 and 0.006 for Kalimantan and Sumatera, respectively, whereas the genetic distance with D. microlepis was 0.142 . The analysis of mutation on RAG2 gene shows there are six nucleotides and three amino acids have mutation.

\section{KEYWORDS: Datnioides sp.; tiger fish; genetic diversity; DNA Barcoding}

\footnotetext{
\# Korespondensi: Balai Riset Budidaya Ikan Hias.

Jl. Perikanan No. 13, Pancoran Mas, Depok 16436, Indonesia.

Tel. + 62217520482

E-mail: m_rinif@ yahoo.com
} 


\section{PENDAHULUAN}

Famili Datnioididae merupakan monotypic yang terdiri satu genus yaitu Datnioides dengan nama sinonim yaitu Coius. Datnioides memiliki enam anggota atau spesies yaitu Datnioides microlepis, D. campbelli, D. pulcher, D. polota, dan D. undecimradiatus, secara umum ikan ini dikenal dengan nama dagang tiger fish atau Siemens Tiger Fish. Di antara kelima spesies tersebut D. microlepis dan D. pulcher, diduga mendiami perairan Indonesia. Khusus spesies D. microlepis lebih dikenal dengan sebutan "The Indonesian tiger fish" ditemukan di perairan Sungai Kapuas, Kalimantan dan Sungai Musi, Sumatera (Wang et al., 2016b).

Ikan tiger fish merupakan ikan hias air tawar yang memiliki nilai ekonomis penting dan permintaannya cukup tinggi terutama untuk pasar ekspor, namun hingga saat ini pemenuhan kebutuhan pasar masih mengandalkan hasil tangkapan alam. Tingginya permintaan dan harga pasar ikan tiger fish telah mendorong terjadinya eksploitasi secara berlebihan terhadap ikan ini di alam. Eksploitasi secara berlebihan dianggap menjadi salah satu faktor ikan ini semakin sulit didapatkan di alam di samping penurunan kualitas habitat dan lingkungan. Di sisi lain kegiatan budidaya ikan tiger hampir untuk semua spesies belum berhasil dilakukan (Nur et al., 2017). Status kepunahan ikan tiger fish telah dipublikasi oleh IUCN dengan tingkatan berbeda di mana $D$. pulcher berada pada status terancam punah (critically endengered), D. undecimradiatus masuk ke dalam kategori rentan (vulnerable) dan tiga spesies lainnya mendekati terancam (near threatened) (http://www.iucnredlist.org).

Di perairan Indonesia genus Datnioidae ditemukan di wilayah Sumatera, Kalimantan, dan Papua dari perairan tawar hingga payau. Menurut Muflikhah \& Dharyati (2010), perairan Indonesia bagian barat di huni dua jenis anggota genus Datnioides yaitu Datnioides microlepis dan D. quadrifasciatus (synonim D. polota). Sebelumnya, Weber \& Beaufort (1936) menyebutkan bahwa ikan ringau hanya ditemukan di Sungai Kapuas.

Ikan tiger fish umumnya menempati perairan yang memiliki tingkat keasaman rendah atau air gambut (peatland atau black water) di Danau Sentani, Kalimantan. Beberapa karakter populasi ikan yang mendiami perairan gambut adalah merupakan populasi kecil dan tingkat endemisitasnya tinggi. Tentu secara ekologi ikan-ikan yang merupakan anggota populasi kecil dan mengalami tekanan karena tingginya tekanan eksploitasi dan kerusakan lingkungan akan mudah sekali mengalami kepunahan atau terancam punah.
Setiap spesies atau populasi memiliki mekanisme untuk memilih lokasi geografis, temporal, ekologi, maupun perilaku (ethologi) (Ryman, 1993), sehingga masing-masing kelompok akan memperlihatkan kekhasan dari masing-masing populasi atau tingkah lakunya. Perbedaan respons dari masing-masing spesies terhadap kondisi ekologi maupun perilaku akan terekspresi pada gen yang mengkode masingmasing respons tersebut (Willmer et al., 2000), atau dikenal dengan keragaman genetik. Perbedaan genetik dapat menyebabkan setiap populasi akan menunjukkan ciri morfologi dan perilaku yang berbeda pula, termasuk ketahannnya terhadap tekanan atau perubahan lingkungan. Keragaman genetik adalah total informasi genetik yang tersimpan dalam gen-gen individu dalam suatu populasi dan mencerminkan kemampuannya beradaptasi dengan perubahan. Secara umum populasi yang memiliki keragaman genetik tinggi lebih mampu beradaptasi terhadap perubahan lingkungan dan sangat berguna sebagai objek pemuliaan (selective breeding) (Kottelat $\&$ Whitten, 1996).

Pemahaman terhadap keragaman genetik ikan menjadi sangat penting dalam upaya pengelolaan dan konservasi ikan. Keragaman genetik sebelumnya dijelaskan dengan keragaman morfologi yaitu morfometrik meristik, namun setelah ilmu biologi mengalami evolusi menjadi biologi molekuler maka studi keragaman genetik pun dilakukan dengan menggunakan pendekatan molekuler, yaitu dengan melihat tingkat mutasi nukleotida (Freenland, 2005). Marka genetik digunakan dalam analisis populasi meliputi DNA mitokondria dan DNA inti.

DNA mitokondria merupakan gen pada sel somatik (sel tubuh) yang memiliki ukuran relatif kecil berkisar $20 \mathrm{~kb}$ yang diturunkan dari tetua betina (Griffiths et al., 2000). DNA mitokondria memiliki tingkat mutasi lima hingga10 kali lebih cepat dibandingkan dengan DNA inti, dengan rata-rata tingkat mutasi adalah $1 \%$ $2 \%$ per satu juta tahun (Randi, 2000). Gen cyochrome b pada mitokondria merupakan gen yang umum digunakan dalam mempelajari keragaman genetik dan pohon kekerabatan (Finnila, 2000). Pada mitokondria juga terdapat gen untuk identifikasi atau DNA barcoding yaitu gen cytochrome oxidase I (COI), namun sebagian ahli juga menggunakan gen $\mathrm{COI}$ ini sebagai marka keragaman genetik dengan asumsi melihat keragaman pada gen-gen yang bersifat lestari (conserve) (El-Nabi et al., 2017). RAG (recombination activating gene) merupakan gen inti yang memiliki fungsi dalam mengatur sistem imunoglobulin dan sel $\mathrm{T}$ dalm tubuh, rantai protein gen RAG relatif panjang sehingga banyak 
digunakan sebagai marka genetik (Lovejoy $\&$ Collette, 2001).

Penelitian ini dilakukan untuk mendapatkan informasi genetik ikan tiger fish (Datnioides sp.) asal populasi Kalimatan dan Sumatera, meliputi identifikasi molekuler dan keragaman genetik. Informasi yang diperoleh selanjutnya dijadikan dasar dalam pengelolaan dan konservasi ikan tiger fish.

\section{BAHAN DAN METODE}

\section{Ikan Koleksi}

Sebanyak 24 sampel ikan tiger fish yang digunakan pada penelitian ini diperoleh dari Sungai Musi, Sumatera Selatan dan Sungai Kapuas, Kalimantan Barat masing-masing sebanyak 12 sampel. Kedua lokasi ini mewakili populasi ikan yang mendiami sungai tua Paparan Sunda (Gambar 1). Ikan ditangkap dengan menggunakan alat tangkap ikan berupa jala dan serokan. Ikan hasil koleksi disimpan dalam alkohol $96 \%$ dan selanjutnya digunakan dalam kegiatan molekuler.

\section{Ekstraksi dan Amplifikasi DNA}

Total DNA (genome) diisolasi dari jaringan sirip ekor (caudal fin). DNA diekstrasi dengan menggunakan metode spin-column mengacu pada prosedur kerja Kit gSYNC DNA Extraction. Kualitas DNA hasil ekstrasi, dilakukan visualisasi DNA dengan bantuan blue light transilluminator ( $\lambda=250 \mathrm{~nm}$ ). DNA total hasil purifikasi ekstrasi selanjutnya digunakan sebagai DNA cetakan (DNA template) untuk proses amplifikasi dengan teknik PolymeraseChain Reaction (PCR). Primer yang digunakan dalam proses PCR, tertera pada Tabel 1 . Kondisi PCR yang digunakan untuk gen $\mathrm{CO}$ I mengacu pada Ward et al. (2005). Sedangkan untuk DNA inti gen RAG2, proses PCR dilakukan sebanyak dua kali (nested PCR) mengacu pada Lovejoy \& Collette (2001).

\section{Pembacaan untai DNA dan analisis data}

Purifikasi DNA dilakukan pada gen RAG2. Amplifikasi gen RAG2 tahap pertama menghasilkan empat pita produk PCR utama yaitu 500 bp, 700 bp, $1.200 \mathrm{bp}$, dan 1.500 bp. Selanjutnya diambil dua produk PCR yang memiliki ketebalan pita tertinggi dengan cara pemotongan gel. Gel yang telah dipotong tersebut diisolasi dan dipurifikasi dengan menggunakan Kit Gel PCR/DNA fragment extraction produksi Geneaid. DNA hasil purifikasi selanjutnya digunakan sebagai DNA template pada PCR tahap kedua. Kondisi PCR tahap kedua sama dengan tahap pertama, namun siklus amplifikasi ditambah sehingga menjadi 50 siklus. Runutan nukleotida hasil PCR selanjutnya dibaca dengan menggunakan Applied Biosystems melalui Macrogen Korea.

Kualitas hasil runutan DNA dicek secara manual untuk mengkoreksi adanya insersi dan delesi nuklotida. Analisis hasil runutan dilakukan untuk

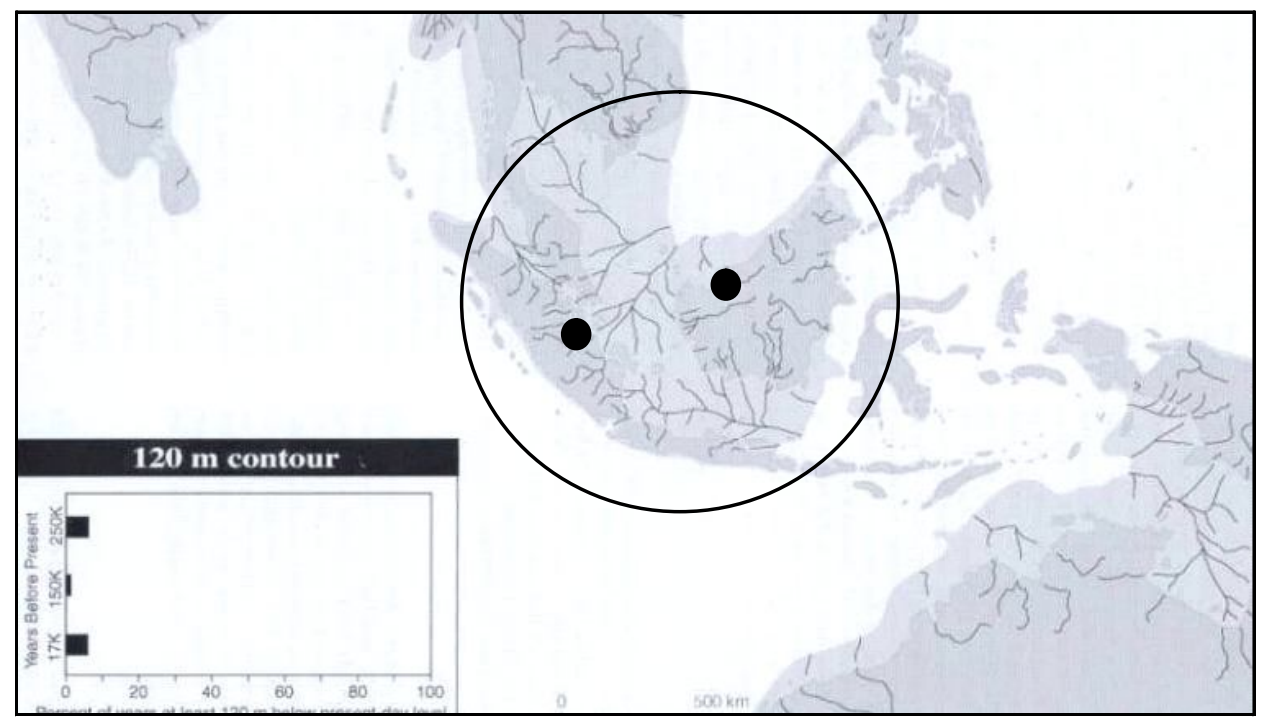

Gambar 1. (•) Lokasi pengambilan sampel ikan tiger fish (Datnioides microlepis) yang mewakili sungai tua Paparan Sunda di perairan Sumatera dan Kalimantan (gambar ilustrasi sungai tua pada masa Pleistocene oleh Voris et al. (2000)).

Figure 1. (•) The Indonesian tiger fish sampling site (Datnioides microlepis) represents the Ancient Sunda Island River in Sumatra and Kalimantan (an ancient river illustration in the Pleistocene era refers to Voris et al. (2000)). 
Tabel 1. Daftar primer yang digunakan pada penelitian ini

Table 1. List of primers that were used in the present study

\begin{tabular}{|c|c|c|c|c|}
\hline $\begin{array}{l}\text { Nama primer } \\
\text { Primer name }\end{array}$ & $\begin{array}{l}\text { Sekuen } \\
\text { Squence }\end{array}$ & $\begin{array}{l}\text { Gen } \\
\text { Gene }\end{array}$ & $\begin{array}{l}\text { Produk PCR } \\
\text { PCR product }\end{array}$ & $\begin{array}{l}\text { Referensi } \\
\text { Reference }\end{array}$ \\
\hline Fish F1 & TCA-ACC-AAC-CAC- AAA- GAC-ATT GGC-AC & \multirow{2}{*}{$\begin{array}{l}\text { Cytochrome } \\
\text { Oxidase } 1 \text { (COI) }\end{array}$} & \multirow{2}{*}{$680 \mathrm{bp}$} & \multirow{2}{*}{ Ward et al . (2005) } \\
\hline Fish R1 & TAG- ACT- TCT- GGG-TGG- CCA- AAG AAT- CA & & & \\
\hline FCyt-Tiger fish & TGA-TGG-AAC-TTT-GGC-TCC-CT & \multirow{2}{*}{ Chytochrome b (Cyt b) } & \multirow{2}{*}{$980 \mathrm{bp}$} & \multirow{2}{*}{$\begin{array}{l}\text { Desain pada } \\
\text { penelitian ini }\end{array}$} \\
\hline RCyt-Tiger fish & GAG-GAG-TTG-AGT-GAG-GGG-TC & & & \\
\hline RAG2F1 & TTT-GGR-CAR-AAG-GGC-TGG-CC & \multirow{2}{*}{$\begin{array}{l}\text { Recombination Activating } \\
\text { Gene } 2 \text { (RAG2) }\end{array}$} & $1,200 \mathrm{bp}$ & \multirow{2}{*}{$\begin{array}{c}\text { Lovejoy \& } \\
\text { Collette (2001) }\end{array}$} \\
\hline RAG2R4 & GTr-Gar-TAG-TAG-GGC-TCC-CA & & $720 \mathrm{bb}$ & \\
\hline
\end{tabular}

masing-masing gen. Analisis gen COI dilakukan untuk identifikasi spesimen dengan menggunakan metode BLAST (http://blast.ncbi.nlm.nih.gov/Blast.cgi) yaitu melalui pembandingan runutan nukleotida yang diperoleh dengan runutan yang terdapat dalam GenBank National Centre for Biotechnology Information (NCBI) (http://www.ncbi.nlm.nih.gov/blast). Persentasi sisi homolog runutan nukleotida gen COI dari spesies yang diperoleh dan hasil penelusuran akan didapatkan persentase kesamaan atau identity similarity.

Analisis keragaman genetik ikan tiger fish dilakukan dengan menggunakan marka DNA mitokondria gen chytochromeb dan DNA inti gen RAG2 (Recombination Activating Gene2). Semua hasil runutan disejajarkan dengan menggunakan CLUSTAL W Multiple alignment yang tersedia pada program MEGA.5.1 (Kumar et al., 2008). Nilai keragaman haplotip (h) dan keragaman nukleotida (p) dianalisis dengan mengunakan program DNAsp versi 5 (Librado \& Rozas, 2009). Komposisi nukleotida, model substitusi dan mutasi, pohon kekerabatan, sertajarak genetik dari kedua populasi dikalkulasi dengan menggunakan program MEGA versi 5. Mutasi nukleotida baik sinonim maupun non-sinonim dianalisis setelah dilakukan pensejajaran (align) dan translasi.

\section{HASIL DAN BAHASAN}

\section{Identifikasi Molekuler dan DNA Barcoding}

Hasil identifikasi molekuler ikan tiger fish asal Kalimantan dan Sumatera menunjukkan bahwa sampel hasil koleksi memiliki kesamaan sebesar 100\%dengan spesies Datnioides undecimradiatus. Analisis terhadap 632 nukleotida hewan uji memperlihatkan kesamaan dengan urutan nukleotida spesies $D$. undecimradiatus pada posisi ke-5.605 hingga posisi ke-6.236 (kode akses NCBI KU870663.1) (Gambar 1). Hasil serupa juga dapat dilihat dari konstruksi pohon kekerabatan antara sekuen hewan hasil uji dan sekuen genus yang sama dari GenBank. Mengacu pada hasil bootstrap konstruksi pohon kekerabatan dengan 1.000 kali perulangan menunjukkan bahwa semua kelompok hewan uji memiliki kesamaan $100 \%$ dengan spesies $D$. undecimradiatus pada posisi nukleotida ke-5.605 hingga 6.236 .

Hasil identifikasi molekuler terhadap ikan tiger fish yang diperoleh dari penelitian ini berbeda dengan identifikasi sebelumnya yang dilakukan oleh Wang et al. (2016b). Berdasarkan data sekuen mitokondria (complete genome) Wang et al. (2016b) menyebutkan bahwa Indonesian tiger fish adalah spesies D. microlepis, sedangkan $D$. undecimradiatus adalah spesies yang mendiami perairan Sungai Mekong. Vidthayanon (2005) menyebutkan bahwa D. undecimradiatus adalah spesies genus Datnioides yang mendiami perairan Sungai Mekong. Roberts \& Kottelat (1993) menyebutkan bahwa ikan ringau atau Indonesian tiger fish (D. microlepis) merupakan salah satu spesies ikan hias air tawar dari famili Datnioididae yang hidup di perairan sungai dan danau di daerah Sumatera dan Kalimantan. Pada tahun 1994, Robert \& Kottelat melakukan publikasi ulang bahwa Indonesian tiger fish (D. microlepis) terdapat di perairan Chao Phraya, Sungai Mekong, Sungai Kapuas, dan Sungai Musi.

\section{Keragaman Genetik Ikan Tiger Fish Populasi Kalimantan dan Sumatera Berdasarkan DNA Mitokondria (mtDNA) dan DNA Inti}

Hasil analisis keragaman genetik semua sampel ikan ikan uji dengan menggunakan metode Maximum Composite Likelihood adalah 0,023 dengan standar deviasi 0,006 . Sedangkan keragaman genetik intra populasi adalah 0,002 untuk populasi Kalimantan dan 0,003 untuk populasi Sumatera, masing-masing memiliki standar deviasi 0,001. Dari 890 nukleotida hasil sekuensing hanya 844 nukeotida yang digunakan untuk analisis keragaman genetik, sedangkan 48 nukleotida tidak diikutkan dalam proses untuk menghindari 


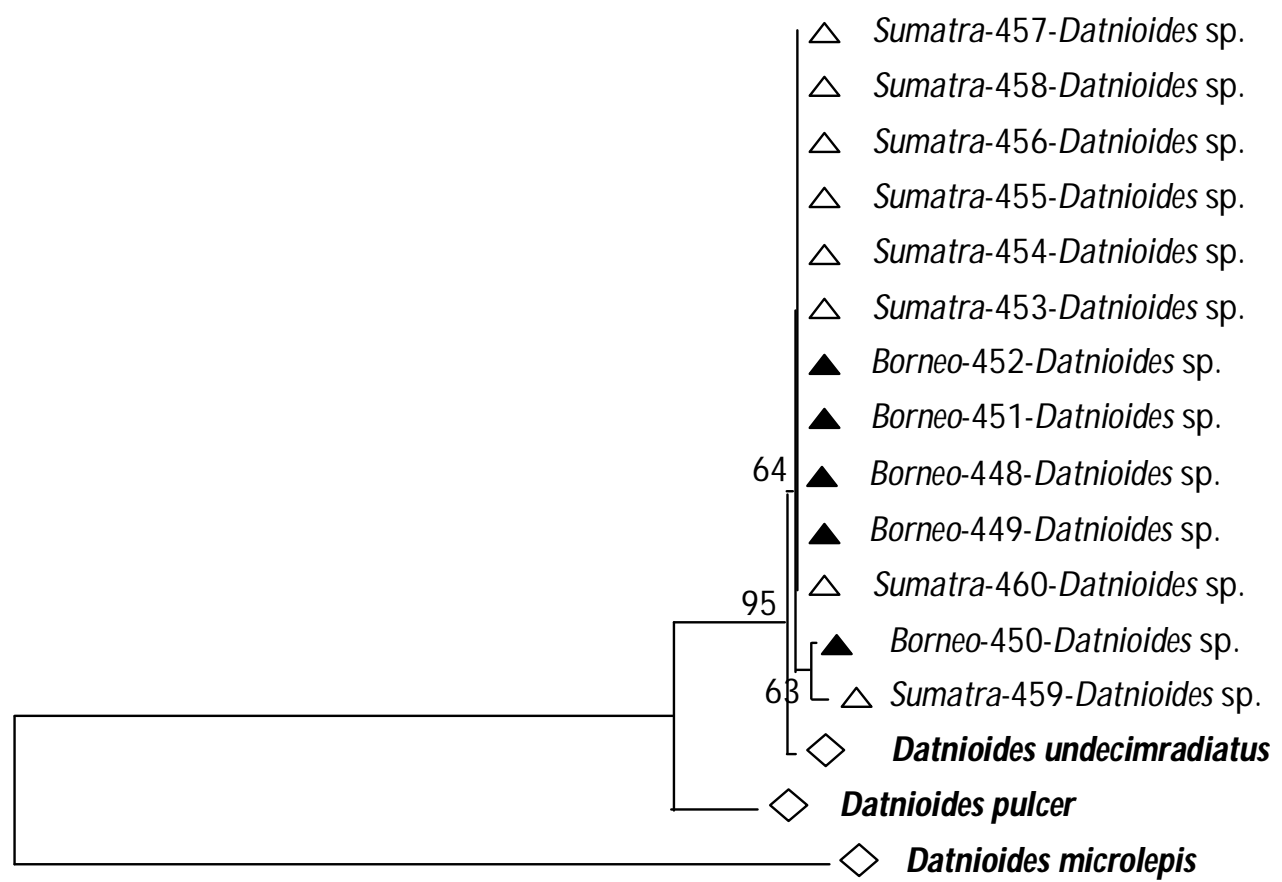

0.01

Gambar 2. Konstruksi pohon kekerabatan neighbour-joining (NJ) gen COI ikan tiger fish dengan 1.000 kali perulangan (bootstrap replication) angka pada akar pohon memunjukkan persentase kesamaan nilai permutasi. $\triangle$ untai DNA sampel populasi Sumatera, $\boldsymbol{\Delta}$ untai sampel populasi Kalimantan, dan $\diamond$ untai DNA dari GenBank).

Figure 2. The construction of neighbour-joining (NJ) phylogenetic tree gene $\mathrm{CO}$ tiger fish with 1,000 repetitions (bootstrap replication), number at the root of the tree indicates the percentage of similarity in permutation values $\triangle D N A$ sequence of sample from Sumatra, $\boldsymbol{\Delta}$ DNA sequence of sample from Kalimantan, and $\diamond$ DNA sequence from GenBank).

ketidakjelasan hasil pembacaan sekuen. Dari 844 nukleotida yang dianalis terdapat sembilan posisi polimorfik untuk semua populasi, masing-masing tiga untuk populasi Kalimatan $(0,35 \%)$ dan enam untuk populasi Sumatera $(0,7 \%$. Hasil analisis substitusi nukleotida dapat dilihat pada Tabel 2 , substitusi transisi lebih tinggi dibandingkan dengan substitusi transversi. Analisis substitusi dilakukan dengan menggunakan metode HKY (Hasegawa Kishino Yano). Pemilihan metode ini mengacu pada nilai BIC (Bayesian Information Criterion), nilai BIC terendah merupakan model substitusi terbaik. Rendahnya keragaman genetik ikan tiger fish diduga disebabkan oleh penurunan populasi ikan di alam dan adanya penyempitan aliran gen (bottleneck) yang terjadi semenjak jutaan tahun yang lalu (Kusumah, 2007).
Hasil penghitungan frekuensi kemunculan masingmasing nukleotida adalah sebagai berikut Adenin (A) 25,08\% Timin (T/U) 28,02\% Cytosin (C) 14,16\% dan Guanin (G) 32,74\% Louie et al. (2003) menjelaskan bahwa distribusi frekuensi nukleotida untuk region coding (exon) dan non-coding (intron) berbeda. Untuk region intron umumnya terjadi gap (perbedaan yang cukup jauh) antara frekuensi CG dan AT, seperti pada hasil penelitian ini perbedaan frekuensi Cytosine dan Guanine cukup jauh yaitu 14,16\%dan 32,74\% Perbedaan frekuensi untuk masing-masing nukleotida menunjukkan terjadinya asimentris proses mutasi, hal ini dapat terjadi pada proses transkripsi.

Mengacu pada pohon kekerabatan Gambar 3 terlihat sampel yang digunakan memiliki hubungan lebih dekat dengan $\mathrm{D}$. undecimradiatus dibandingkan 
Tabel 2. Substitusi nukleotida gen cyt b berdasarkan Maximum Composite Likelihood

Table 2. The nucleotide substitution of cyt $b$ gene based on Maximum Composite Likelihood

\begin{tabular}{ccccc}
\hline & A & T & C & G \\
\hline A & - & 7.51 & 8.78 & $\mathbf{0 . 0 5}$ \\
$\mathbf{T}$ & 6.73 & - & $\mathbf{2 4 . 9 1}$ & 3.8 \\
$\mathbf{C}$ & 6.73 & $\mathbf{2 1 . 3 2}$ & - & 3.8 \\
$\mathbf{G}$ & $\mathbf{0 . 0 8}$ & 7.51 & 8.78 & - \\
\hline
\end{tabular}

Keterangan: Tulisan cetak tebal (bold) adalah substitusi transisi dan tulisan cetak miring (italics) adalah substitusi transversi

Note: Bold text is a transitional substitution and italics is a transcription substitution)

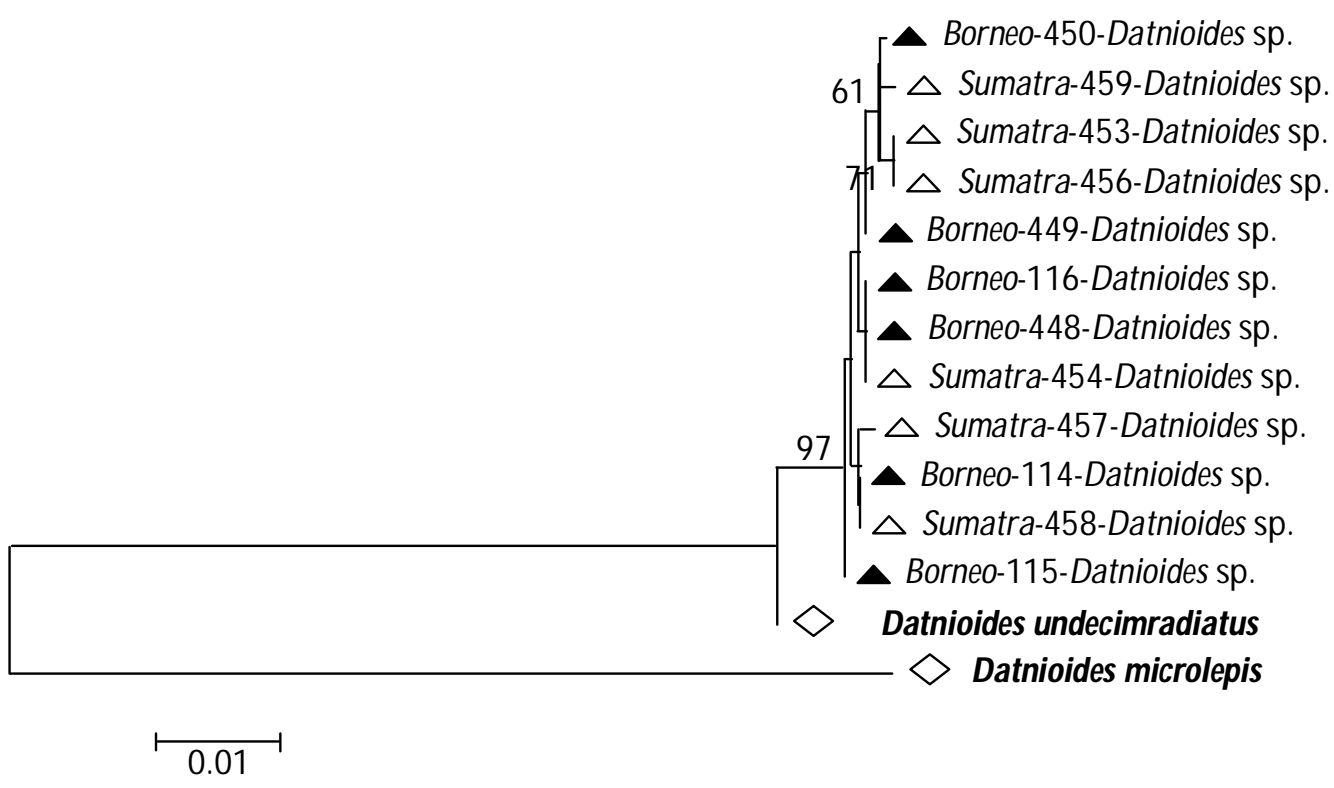

Gambar 3. Pohon kekerabatan neighbour-joining (NJ) gen Cyt b ikan tiger fish populasi Kalimantan dan Sumatera dengan 1.000 kali perulangan (bootstrap replication) angka pada akar pohon menunjukkan persentasi kesamaan nilai permutasi. ( $\triangle$ untai DNA sampel populasi Sumatera, $\mathbf{\Delta}$ untai sampel populasi Kalimantan, dan $\diamond$ untai DNA dari GenBank).

Figure 3. Neighbour-joining (NJ) phylogenetic tree genes Cyt b of tiger fish from Kalimantan and Sumatra with 1,000 times of repitition (bootstrap replication) number at the root of the tree indicates the percentage of similarity in permutation values ( $\triangle \mathrm{DNA}$ sequence of sample from Sumatra, $\boldsymbol{\Delta}$ DNA sequence of sample from Kalimantan, and $\diamond$ DNA sequence from GenBank).

dengan jenis $D$. microlepis. Kondisi ini sama dengan pohon kekerabatan berdasarkan gen COI dengan nilai permutasi $97 \%$ Jarak genetik antar populasi dan intra populasi juga menunjukkan hasil yang sama, data pada Tabel 3, memperlihatkan jarak genetik sampel yang berasal dari Sumatera dan Kalimantan dengan spesies D. undeciumradiatus masing-masing 0,003 dan 0,006. Jarak genetik ini lebih dekat dibandingkan dengan jarak genetik terhadap spesies D. microlepis yaitu 0,142.
Konstruksi dendogram genetika populasi ikan tiger fish berdasarkan DNA inti RAG2 menunjukkan sampel yang diuji terbagi menjadi dua grup berbeda yaitu Sumatera dan Kalimantan seperti pada Gambar 4 dengan jarak genetik antar grup adalah 0,007 (berdasarkan Kimura-2 Parameter). Perbedaan po pulasi didasari pada mutasi nukleotida baik pada kodon pertama maupun kodon ketiga. Mutasi nukleotida ke774 tidak menyebabkan terjadinya perubahan asam 
Tabel 3. Jarak genetik antar populasi berdasarkan gen cyt $b$

Table 3. Genetic distance between populations based on cyt $b$ gene

\begin{tabular}{lcccc} 
& $(1)$ & $(2)$ & $(3)$ & $(4)$ \\
\hline Kalimantan (1) & & 0.001 & 0.003 & 0.034 \\
Sumatera/Sumatra (2) & $\mathbf{0 . 0 0 3}$ & & 0.003 & 0.034 \\
D. undeciumradiatus (3) & $\mathbf{0 . 0 0 6}$ & $\mathbf{0 . 0 0 8}$ & & 0.033 \\
D. microlepis (4) & $\mathbf{0 . 1 4 2}$ & $\mathbf{0 . 1 4 2}$ & $\mathbf{0 . 1 3 3}$ & \\
\hline Keterangan: Tulisan cetak tebal (bold) adalah jarak genetik dan tulisan cetak miring (italics) \\
Note: $\quad$ adalah standar deviasi \\
$\quad$ Bold text is the genetic distance and italic is the standard deviation
\end{tabular}

amino, sedangkan mutasi nukelotida pada posisi 838 , 851, 860, dan 862 masing-masing menyebabkan terjadinya perubahan asam amino seperti disajikan pada Tabel 5.

Hasil penghitungan jarak genetik berdasarkan keragaman nukleotida gen inti (RAG2) memperlihatkan nilai yang lebih tinggi dibandingkan dengan perhitungan jarak genetik berdasarkan keragaman nukleotida gen mitokondria (cyt b dan COI). Smith \& Lee (2008) menyebutkan bahwa walaupun konsep yang selama ini menyebutkan bahwa tingkat mutasi pada gen mitokondria lebih tinggi dibandingkan dengan gen inti, namun laju mutasi masing-masing bagian dalam gen inti menunjukkan tingkat yang berbeda. Beberapa bagian di antaranya memiliki tingkat mutasi yang lebih tinggi seperti pada region intron dan silent site.

Rendahnya jarak genetik antar populasi mengindikasikan bahwa kedua populasi memiliki hubungan kekerabatan secara geografis pada dekade sebelumnya atau pernah terjadi aliran genetik dari kedua populasi. Kehadiran konstruksi sungai tua di Paparan Sunda oleh Voris (2000) mendukung informasi genetik yang diperoleh pada penelitian ini. Jika mengacu pada data struktur populasi ikan Botia (Hidonis, 2008) di mana perbedaan genetik untuk masing-masing populasi Kalimantan dan Sumatera adalah 6,29\%6,32\% maka diperkirakan kedua po pulasi terpisah semenjak 9,25-9,46 juta tahun yang lalu (Zaman Miocene). Sedangkan data yang diperoleh pada penelitian yakni jarak genetik sekitar 2,3\% maka diperkirakan kedua populasi terpisah sekitar 3,38 juta huan yang lalu (Zaman Pliosen). Estimasi evolusi ini diperoleh dari laju mutasi pada DNA mitokondria sebesar $0,68 \%$ setiap satu juta tahun. Doardio \& Perdices (2005) menyebutkan bahwa perbedaan genetik untuk Familli Cobitidae adalah sebesar 0,68\% per satu juta tahun. Perbedaan kondisi perairan di kedua populasi menyebabkan terjadinya mutasi nukleotida ikan pada masing-masing populasi sebagai strategi untuk dapat bertahan hidup (adaptasi) (Frankham et al., 2007).

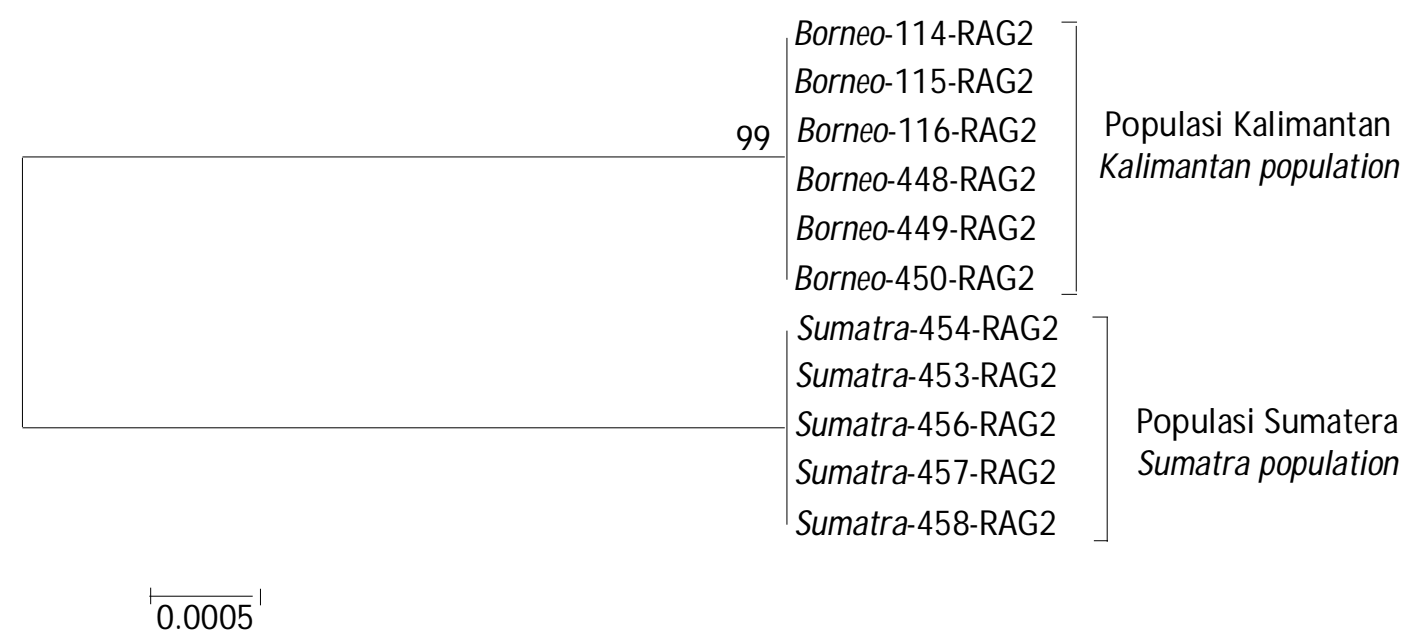

Gambar 4. Dendogram genetika populasi ikan tiger fish asal Kalimantan dan Sumatera berdasarkan gen RAG2.

Figure 4. Dendrogram of genetics populations of tiger fish from Kalimantan and Sumatera based on RAG2 gene. 
Tabel 4. Mutasi nukelotida gen RAG2 ikan tiger fish populasi Kalimantan dan Sumatera Table 4. Mutation of nucleotides RAG2 gene of tigerfish fish population Kalimantan and Sumatra

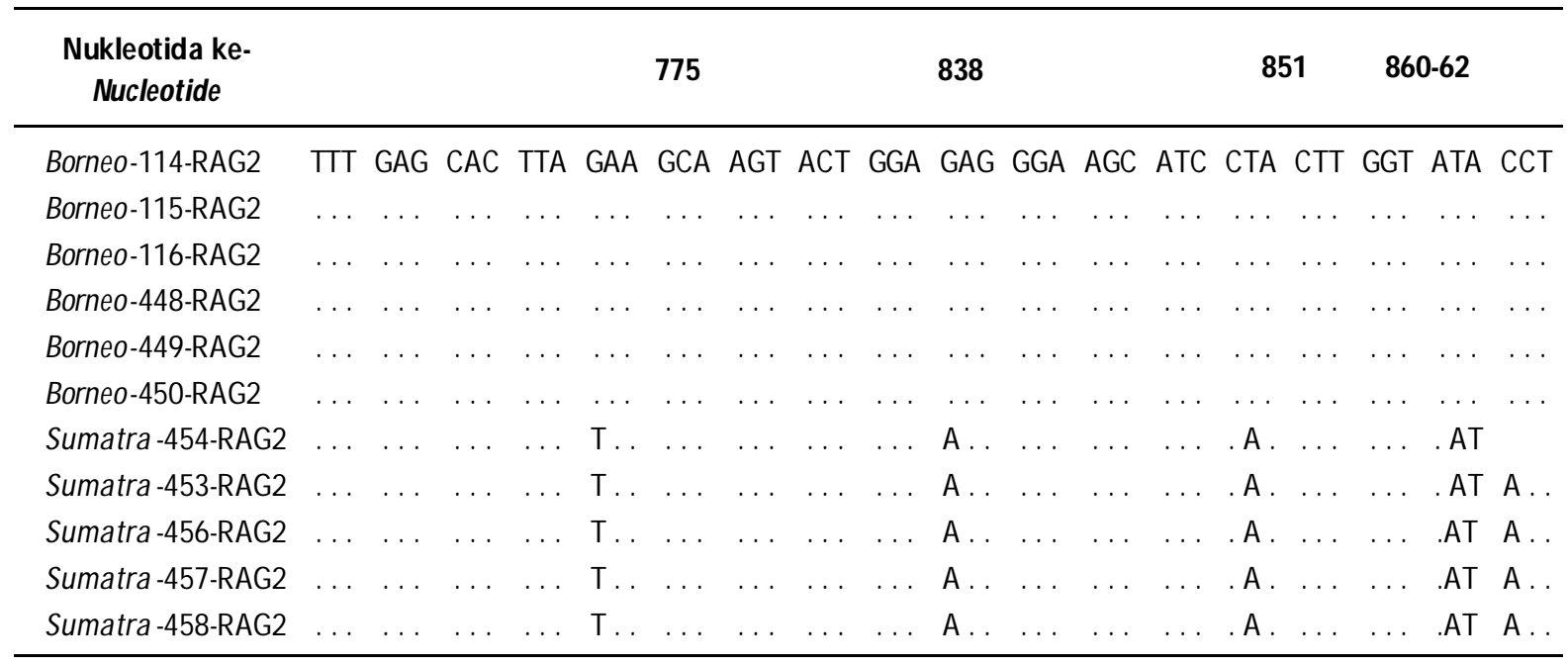

Tabel 5. Mutasi asam amino gen RAG2 ikan tiger fish populasi Kalimantan dan Sumatera Table 5. Mutations of amino acids RAG2 gene of tiger fish from Kalimantan and Sumatra populations

\begin{tabular}{|c|c|c|c|c|c|}
\hline $\begin{array}{l}\text { Asam amino ke- } \\
\text { Amino acids }\end{array}$ & & & & 280 & 288 \\
\hline Borneo-114-RAG2 & MECSTVTLDE & KGIHFEHLEA & PKWIPDIIHS & RTW FGGSTGE & GSILLGIP \\
\hline Borneo-115-RAG2 & $\ldots$ & $\ldots \ldots \ldots$ & $\ldots \ldots \ldots$ & $\ldots$ & $\ldots \ldots \ldots$ \\
\hline Borneo-116-RAG2 & & & $\ldots$ & $\ldots$ & $\ldots \ldots$ \\
\hline Borneo-448-RAG2 & & & & .. & .. \\
\hline Borneo-449-RAG2 & & $\ldots$ & $\ldots$ & $\ldots$ & $\ldots$ \\
\hline Borneo-450-RAG2 & & $\ldots$ & $\ldots \ldots \ldots$ & $\ldots \ldots$ & $\ldots$ \\
\hline Sumatra -454-RAG2 & $\ldots$ & $\ldots \ldots *^{*}$ & $\ldots \ldots \ldots$ & $\ldots \ldots k$ & $\ldots Q \ldots N T$ \\
\hline Sumatra -453-RAG2 & $\ldots \ldots \ldots$ & $\ldots \ldots *^{*}$ & $\ldots \ldots \ldots$ & $\ldots k$ & $\ldots Q \ldots N T$ \\
\hline Sumatra -456-RAG2 & & $\ldots *$. & & $\ldots \mathrm{K}$ & $\ldots Q \ldots N T$ \\
\hline Sumatra -457-RAG2 & & $\ldots *$. & & $\ldots k$ & $\ldots Q \ldots N T$ \\
\hline Sumatra -458-RAG2 & $\ldots \ldots \ldots$ & $\ldots \ldots \ldots *$ & $\ldots \ldots \ldots$ & $\ldots k$ & $\ldots Q \ldots N T$ \\
\hline
\end{tabular}

Para ilmuwan telah mendeskripsikan sekitar 100 juta tahun yang lalu landasan kontinen Indonesia secara umum terbagi menjadi dua bagian yaitu Paparan Sunda, yang menghubungkan tiga pulau besar yaitu Sumatera, Kalimantan, dan Jawa, serta Paparan Sahul (meliputi New Guinea dan Australia). Hipotesa tersebut didukung oleh bukti-bukti ilmiah adanya kekerabatan flora dan fauna yang mendiami pulaupulau tersebut (Sudarto, 2003).

\section{KESIMPULAN}

Identifikasi molekuler ikan tiger fish hasil koleksi populasi Sumatera dan Kalimantan memiliki tingkat kesamaan $100 \%$ dengan D. undeciumradiatus. Keragaman genetik antar populasi 0,023 dan intrapopulasi adalah 0,002 dan 0,003 masing-masing untuk populasi Kalimantan dan Sumatera. Genetika populasi ikan tiger fish berdasarkan DNA inti menunjukkan sampel hasil koleksi terbagi menjadi dua kelompok yaitu populasi Kalimatan dan populasi Sumatera dengan jarak genetik antar populasi 0,007.

\section{UCAPAN TERIMA KASIH}

Penulis mengucapkan terima kasih kepada DIPA APBN Balai Riset Budidaya Ikan Hias (BRBIH) 2016 yang telah mendanai penelitian ini.

\section{DAFTAR ACUAN}

Doadrio, I. \& Perdices, A. (2005). Phylogenetic relationships among the Ibero-African Cobitids 
(Cobitis, Cobitidae) based on Cytochrome b sequence data. Molecular Phylogenetic Evolution, 37, 484-493.

El-Nabi, E.H., El Desoky, M.S., \& Geba, K.M. (2017). Genetic population diversity of European eel Anguilla anguilla elvers in two Egyptian water bodies, Rosetta (Rachid) estuary and Burullus Lake. Genes Genom., DOI: 10.1007/s13258-0170572-1.

Finnila, S. (1999). Phylogenetic analysis of mithocondrial DNA detection of mutation in patients with occipital stroke. Oulu, $71 \mathrm{pp}$.

Frankham, R., Ballau, J.D., \& Briscoes D.A. (2007). Introduction to conservation genetic. Cambridge University Press.

Freenland, J.R. (2005). Molecular ecology. West Sussex, England: John Wiley \& Sons Ltd., p. 31-60.

Griffiths, A.J.F., Miller, J.H., \& Suzuki, D.T. (2000). An introduction to genetic analysis. 7th edition. New York: W.H. Freeman.

Hidonis, K. (2008). Genetic differentiation among populations of Chromobotia macracanthus Bleeker from Sumatra and Kalimantan based on sequencing gene of MtDNA Cytochrome $b$ and Nucleus DNA RAG2. Skripsi. Fakultas Parikanan dan IImu Kelautan. Institut Pertanian Bogor.

Kottelat, M. \& Whitten, A.J. (1996). Freshwater biodiversity in Asia with special reference to fish. Washington, USA: World Bank Technical Paper, $343 \mathrm{pp}$.

Kumar, S., Nei, M., Dudley, J., \& Tamura, K. (2008). MEGA: A biologist-centric software for evolutionary analysis of DNA and protein sequence. Brief. Bioinformatics, 9(4), 299-306.

Kusumah, R.V. (2007). Struktur populasi dan sejarah kolonisasi ikan Botia (Chromobotia macracanthus Blekeer) berdasarkan Sequence (urutan basa) intron dari gen Aldolase B. Skripsi. Fakultas Perikanan dan IImu Kelautan. Institut Pertanian Bogor.

Librado, P. \& Rozas, J. (2009). DnaSP v5: a software for comprehensive analysis of DNA polymorphism data. Bioinformatic, (25)11, 1451-1452.

Louie, E., Ott J., \& Majewski, J. (2003). Nucleotide frequency variation across human genes. Genome Research, 13, 2594-2601.

Lovejoy, N.R. \& Collette, B.B. (2001). Phylogenetic relationships of New World Needlefishes (Teleostei: Belonidae) and the biogeography of transitions between marine and freshwater habitats. Copeia, 2, 324-338.

Muflikhah, N. \& Dharyati, E. (2010). Studi biologi ikan ringau (Datnioides microlepis) di Daerah Aliran Sungai
Kapuas, Kalimantan Barat. Prosiding Seminar Nasional Biologi. Fakultas Biologi, Universitas Gajah Mada. Yogyakarta, 24-25 September 2010.

Nur, B., Sudrajat, A.O., \& Fahmi, M.R. (2017). Penggunaan serotonin dalam formulasi hormon pregnant mare serum gonadotropin dan antidopamin untuk menginduksi perkembangan gonad ikan ringau, Datnioides microlepis Bleeker, 1854. Jurnal Iktiologi Indonesia, 17(1), 29-43.

Randi, E. (2000). Mithocondrial DNA. In Beker, A.J. (Ed.). Molecular methods in ecology. Oxpord: Blackwell Science, p. 136-167.

Roberts, T.R. \& Kottelat, M. (1994). The Indo-Pacific tigerperches, with a new species from the Mekong basin (Pisces: Coiidae). Ichthyol. Explor. Freshwat., 5, 257-266.

Ryman, N. (1993). Conservation genetics considerations in fishery management. Journal of Fish Biology, 39, 211-224.

Smith, D.R. \& Lee, R.W. (2008). Nucleotide diversity in the mitochondrial and nuclear compartments of Chlamydomonas reinhardtii: investigating the origins of genome architecture. BMC Evolutionary Biology, 8, 156.

Sudarto. (2003). Systematic revision and phylogenetic relationships among populations of clariid species in Southeast Asia. Thesis. University of Indoneisa, 271 hlm.

Voris, H.K. (2000). Maps of Pleistocene sea levels in Southeast Asia: shorelines, river systems and time durations. Journal of Biogeography, 27, 1153-1167.

Vidthayanon, C. (2005). Thailand red data: fishes. Bangkok, Thailand: Office Natural Resources and Environmental Policy and Planning, $108 \mathrm{pp}$.

Ward, R.D., Zemlak, T.S., Innes, B.H., Last, P.R., \& Hebert, P.D.N. (2005). DNA barcoding Australia's fish species. Philos. Trans. R. Soc. Lond. B. Biol. Sci., 1462, 1847-1857.

Wang, L., Chen, Z., Gao, J., Zhao, Y., Sun, P., \& Lu, K. (2016a). The complete mitochondrial genome of Mekong tiger fish Datnioides undecimradiatus (Roberts \& Kottelat, 1994). Mitochondrial DNA Resources, 1(1), 367-368.

Wang, L., Chen, Z., Gao, J., Zhao, Y., Sun, P., \& Lu, K. (2016b). The complete mitochondrial genome of Indonesia tiger fish, Datnioides microlepis (Bleeker 1854). Mitochondrial DNA Resources, 1(1), 328-329.

Weber, M. \& de Beaufort, L.F. (1936). The fishes of the Indo-Australian Archipelago VII. Perciformes (continued). Brill, Leiden, XII, 1-607.

Willmer, P., Stone G., \& Johnston, I. (2000). Environmental physiology of animals. Blackwell Science, p. 1-45. 